\title{
Quality of public urban parks for physical activity practice in Bucaramanga, Colombia
}

\section{Qualidade dos parques públicos urbanos para a prática de atividades físicas em Bucaramanga, Colômbia}

\author{
Paula Camila Ramírez $z^{1,2}$ \\ Diana Marina Camargo ${ }^{1}$ \\ Vanessa Quiroga ${ }^{3}$ \\ Ana Paola Rios ${ }^{4}$ \\ Rogério César Fermino $0^{5,6}$ \\ Olga L. Sarmiento 4
}

\begin{abstract}
The characteristics of parks (availability, accessibility, conservation, quality, safety, etc.) are important predictors of their use for physical activity practices. The aim of this study was to verify the association among the socioeconomic level of neighborhoods, the characteristics and quality of urban public parks for physical activity in Bucaramanga, Colombia. Cross-sectional study, conducted in 2015, in which 10 parks with structures for physical activity were evaluated. The socioeconomic level of the district was evaluated based on the neighborhoods around the parks and classified in "low" and "high". The number of residents in the surrounding area of parks were evaluated with Geographic Information System (GIS), site characteristics and quality with the System for Observing Play and Recreation in Communities (SOPARC) and the Physical Activity Resource Assessment (PARA), respectively. The association was analyzed with Mann Whitney U test and Spearman correlation (rho) on STATA 14 and the significance level was maintained at $5 \%$. A positive association was found between the socioeconomic level and the presence of walking paths (marginal, $\mathrm{p}=0.056$ ), accessibility ( $\mathrm{rho}=0.875 ; \mathrm{p}=0.001$ ) and general quality of parks ( $\mathrm{rho}=0.657 ; \mathrm{p}=0.039)$. The low socioeconomic level was associated with the presence of sports courts $(\mathrm{p}=0.032)$. These results can guide the actions of public managers for the modification of the built environment and structures of the parks for physical activity.
\end{abstract}

Key words: Environment; Green Areas; Motor Activity; Parks; Social Class.

Resumo - As características dos parques (disponibilidade, acessibilidade, conservação, qualidade, segurança, etc.) são importantes preditores da sua utilização para a prática de atividades físicas. O objetivo deste estudo foi verificar a associação entre o nivel socioeconômico dos bairros com as características e a qualidade dos parques públicos urbanos para a prática de atividades físicas em Bucaramanga, Colômbia. Estudo transversal, realizado em 2015, no qual foram avaliados 10 parques com estruturas para atividades físicas. O nível socioeconômico da região foi avaliado com base nos bairros próximos aos parques e classificado em "baixo" e "alto". O número de residentes próximos foi avaliado com o Sistema de Informação Geográfica (SIG), as características do local e a qualidade foram avaliadas, respectivamente, com o System for Observing Play and Recreation in Communities (SOPARC) e o Physical Activity Resource Assessment (PARA). A associação foi analisada com o teste $U$ de Mann Whitney e a correlação de Spearman (rho) no STATA 14 e o nivel de significância mantido em 5\%. Foi verificada associação positiva entre o nivel socioeconômico e a presença de pistas de caminhada (marginal, $p=0,056$ ), acessibilidade $(r h o=0,875 ; p=0,001)$ e qualidade geral dos parques (rho=0,657; $p=0,039)$. O baixo nível socioeconômico foi associado à presença de quadras para esportes $(p=0,032)$. Esses resultados podem orientar as açôes dos gestores públicos para a modificação do ambiente construído e estruturas dos parques para a atividade física.

Palavras-chave: Areas verdes; Atividade motora; Classe social; Meio ambiente; Parques Recreativos.
1 Universidad Industrial de Santander. School of Physical Therapy. Research Group in Movement, Harmony and Life. Bucaramanga. Colombia.

2 Universidad Santo Tomás. Research Group in Being, Culture and Movement. Bucaramanga. Colombia.

3 Universidad Industrial de Santander. School of Civil Engineering. Research Group in Geomatics, Management and Systems Optimization. Bucaramanga. Colombia.

4 Universidad de los Andes. School of Medicine. Group of Epidemiology at the University of los Andes. Bogota D.C. Colombia.

5 Federal University of Technology - Parana. Postgraduate Program in Physical Education. Research Group in Environment, Physical Activity and Health. Curitiba, PR. Brazil.

6 Pontifical Catholic University of Parana. Research Group in Physical Activity and Quality of Life. Curitiba, PR. Brazil.

Received: 13 June 2017 Accepted: 14 August 2017 


\section{INTRODUCTION}

Characteristics of the built environment are positively associated with leisure time physical activity ${ }^{1}$. In this sense, the access to locations such as parks, plazas and bicycle routes becomes important for the development of active healthy lifestyles in the population ${ }^{2-5}$. Aspects such as the availability of areas for walking, green areas and access to recreational facilities as well as the aesthetics of the surroundings are positively associated with physical activity ${ }^{1,2,6}$.

Different characteristics of parks may influence its use ${ }^{2,6}$. Among them are accessibility, availability, conservation and quality, land use, programming, safety and services offered ${ }^{2,4,6-11}$. The availability, access, characteristics and quality of public open spaces are associated to the socioeconomic level of neighborhoods ${ }^{12}$. Evidence shows that living in areas of low socioeconomic level is inversely associate to physical activity, which could be explained by lack of adequate spaces for practice ${ }^{13-15}$. This is important, once in Colombia (Bogotá) it was found that $55 \%$ of the population uses parks and plazas for physical activity and, moreover, that the use of these spaces can increase in 310\% the likelihood of reaching the recommendations of physical activity for health, in leisure time ${ }^{5}$.

Evidence of quality and availability of public open spaces and its use for physical activity has been published in the past years ${ }^{4}$. Nonetheless, most of the studies were conducted in high-income countries such as United States, Canada and Australia ${ }^{4,16-18}$, which may not represent the sociocultural and urban reality of middle-income countries such as those in Latin America ${ }^{1}$. In Brazil, three studies assessed the presence and quality of public open spaces for physical activity in the cities of Rio de Janeiro-RJ and Pelotas-RS, and results showed that most locations have adequate structures, beyond the safety issue, cleanliness and other structures for usercomfort ${ }^{12,19,20}$.

In Colombia, no studies have been conducted on the quality of public urban parks for physical activity practice and its relationship with socioeconomic levels of the neighborhoods where they are located. The understanding of this relationship is important for local managers to be able to redirect interventions, to improve the quality of parks for physical activity in the community level.

The aim of this study was to analyze the association between the socioeconomic level of neighborhoods and the characteristics and quality of public urban parks for physical activity in Bucaramanga, Colombia.

\section{METHODOLOGICAL PROCEDURES}

\section{Study location}

Bucaramanga is in the North oriental zone of Colombia, over the mountains, at 959 meters above sea level. With an area of $165 \mathrm{~km}^{2}$, populations of 528 thousand inhabitants and mean temperature of $23^{\circ} \mathrm{C}$, with a warm climate in most months. It is a city of intermediate size, capital of the 
Santander and is divided into 17 regions, which include neighborhoods, settlements, and urbanized areas. A region is an administrative unit in which the urban area is divided and aggregates different neighborhoods.

The architecture of Bucaramanga was influenced by colonial heritage. Until the second half of the $19^{\text {th }}$ century there were plazas conceived as a signal of progress and liberty, in which symbols and heroes of the nation were recognized, but there was a lack of aesthetics and environmental values. From the second half of the $19^{\text {th }}$ century and until about half of the $20^{\text {th }}$ century, Bucaramanga went through an economic up growth and civil processes where the inhabitants supported urban changes, influenced by those living in the capital, Bogota, and many cities abroad. In this period a significant transformation of plazas and parks occurred. In 1920, institutions were created to preserve the beauty and urban memory of the city, as the Sociedad de Mejoras Públicas y la Academia de Historia (Society for Public Improvement and History Academia, in English).

This process of transformation was so significant for the country that, in the $20^{\text {th }}$ century, Bucaramanga was called “the city of parks". In 2015, the World Bank declared it the most prosperous city in Latin America and an example to the world. Moreover, the city has united with the initiative " $\mathrm{Up}$ coming and sustainable cities" of the Inter-American Development Bank, which highlighted the city shows an important deficit of public space, with $4.5 \mathrm{~m}^{2} /$ inhabitant, while the international level is of $10-15 \mathrm{~m}^{2}$ inhabitant.

\section{Project, design and ethical aspects}

The data for this study are part of the project entitled "Actividad fisica $y$ parques en Bucaramanga, caracterización y factores relacionados con su uso" (in English, Physical activity and parks in Bucaramanga, characterization and factors related to use), an observational and cross-sectional study. The project was approved by the ethics committee for human investigation of the School of Health at the Industrial University of Santander (7083 \#12 of May 23 ${ }^{\text {rd }}$, 2014).

\section{Selection of parks}

According to the Director Plan for Territory of Bucaramanga, there are two regional parks, eight metropolitan parks, six proposed of metropolitan scale, eight with a zonal scale, 31 parks at a local scale and 18 pocket parks in the 17 regions. Public parks, with free access and classified in the category of "local/zonal parks", that offered spaces for free sport, child and adult play, active and passive recreation were selected ${ }^{21}$.

Ten parks were intentionally selected (figure 1 and table 1), representative of the same number of regions. Five of the regions were excluded because there were no parks that would fill the criteria and other two did not present minimum safety conditions for data collection.

\section{Training and data collection}

Between July and August 2015, the data collection team was trained, a total 
of six surveyors. The observers were trained by researchers who previously applied the System for Observing Play and Recreation in Communities (SOPARC) protocol. The training included a theory and practice component. The theory component was conducted by an expert during three-day workshop (16 hours), in which trained observers were familiarized with the SOPARC method (operational definitions, instruments notation and coding conventions). SOPARC training materials, available at the Active Living Research website ${ }^{22}$ were used to train observers as well. The practice component was conducted in two days (six hours) through work field in parks, comparing results between observers and receiving feedback from coordinators, a total of 19 hours of training. The parks were evaluated between August and December 2015.

\section{Independent variable - neighborhood income}

Neighborhood income was classified according to the categories available in Colombia, in six levels, from one (lower) to six (higher). The levels one through three were classified as "low" and correspond to the area in which inhabitants have less resource and are subsidized by the government. Levels four through six correspond to the "high" socioeconomic level, and pay contribution on public services ${ }^{23}$. For this study, the park socioeconomic level was calculated by the sum of the strata of each building and divided by the number of buildings in a service area of 500 meters surrounding the park by the road network. Therefore, parks were classified into two groups, "low" (1-3) and "high" (4-6) socioeconomic level.

\section{Dependent variables}

- Number of people within $\mathbf{5 0 0}$ meters of a park and park area

The number of people within 500 meters of a park and park area $\left(\mathrm{m}^{2}\right)$ were calculated with a Geographic Information System (GIS) with secondary data from the national ${ }^{24}$, with a road network buffer of 500 meters from the centroid point in each park, using software ArcGIS 9.0.

\section{- Target areas for physical activity}

To evaluate the target areas for physical activity, SOPARC protocol was used, developed to obtain observational data in public places ${ }^{25}$. SOPARC has been widely used to evaluate parks and public open spaces in the community and has been used recently in Latin America ${ }^{8,26,27}$.

\section{- Evaluation of target areas}

Target areas are pre-selected of parks, characterized by allowing physical activity (e.g. courts, fields, walking/running tracks, exercise areas). All selected parks were visited and potential target areas identified for the data collection. We created maps for each park delimitating target areas which were evaluated and coded according to the type of areas (e.g.: field, walking/running track) as well as the presence of structures for physical activity (lines, soccer goal posts, etc.) and surface (grass, concrete, etc.). In 
addition, the conditions (accessible, usable, equipped, supervised, organized, dark, empty) of selected areas were assessed with yes $/$ no $^{25}$. SOPARC observations were conducted by four trained observers under the supervision of two field coordinators.

\section{- Quality of parks for physical activity}

The Physical Activity Resource Assessment (PARA) instrument was developed to systematically identify and describe the type, features, amenities, and quality of physical activity resources in urban neighborhoods ${ }^{14,28}$. This instrument was translated and adapted to the Latin American context ${ }^{29}$ and has been used recently in Latin America regions ${ }^{12,29}$. The evaluation was conducted by one field coordinator.

The adapted PARA identifies and qualifies the conditions of parks into six domains: 1) features for physical activity (e.g.: fields and courts for sports, exercise areas, trails for walking, running, skateboarding and roller skating, swimming pool, playgrounds); 2) amenities (e.g.: bathroom, benches, locker room, lighting, trash cans, picnic tables); 3) incivilities (e.g.: cleaning, aesthetics and safety - dog waste, garbage, broken glass, graffiti/ tagging, vandalism, overgrown grass, stray dogs, litter); 4) services (e.g.: presence of coffee shops, food carts, loan of materials for physical activity, physical activity sessions); 5) accessibility (e.g.: presence of taxi and bus stops, parking, bike rack and bicycle path) and 6) safety (e.g.: presence of police station, police and private security).

The features and amenities items were classified into four categories: "not present" (cod.: 0), "poor" (cod.: 1), "mediocre" (cod.: 2), and "good" (cod.: 3). Incivilities items were classified into "not present" (cod.: 3) "a little" (cod.: 2) "some” (cod.: 1) or "a lot" (cod.: 0). Services, accessibility and security items were classified into "absence" (cod.: 0) and "presence" (cod.: 1). The quality score in each domain was computed as the sum of items described above. General park quality was calculated by the sum of the six domains (features + amenities + incivilities + accessibility + services + safety).

\section{Data analysis}

The distribution of quantitative variables was analyzed with Shapiro-Wilk test. Even though some of the variables did not present normal distribution, we opted for the parameters of mean, standard deviation, minimum and maximum, by socioeconomic level ("low" and "high"), to increase comparability with other studies. On the contrary, the dichotomous variables were described in frequency and relative frequency. Due to the reduced number of parks, mean values were compared between socioeconomic level ("low" and "high") with U Mann Whitney test. The association between socioeconomic level of the region and the dependent variables was analyzed with Spearman correlation coefficient (rho). The data were analyzed in STATA (v. 14.0, StataCorp, Texas USA) software and level of significance was maintained at $5 \%$. 


\section{RESULTS}

\section{Descriptive characteristics of parks}

The mean size of the 10 parks evaluated was $123,000 \mathrm{~m}^{2}$; with a total of 139 target with a mean of $198.4 \mathrm{~m}^{2}$. The Parque de Los Niños located in a high income neighborhood had the largest area $\left(31,912.5 \mathrm{~m}^{2}\right)$, the larger number of target areas for physical activity $(\mathrm{n}=24)$ and largest area of target areas $\left(5,758.2 \mathrm{~m}^{2}\right)$. The Parque Comuneros was the largest within low socioeconomic level $\left(7,161.8 \mathrm{~m}^{2}\right)$, with a total of 11 target areas for physical activity and largest area of target areas $\left(3,588.9 \mathrm{~m}^{2}\right)$. The Parque La Iglesia (La Joya) was the smallest $\left(4,183.6 \mathrm{~m}^{2}\right)$, had fewer target areas for physical activity $\left(1,050.0 \mathrm{~m}^{2}\right)$ and is located in a low socioeconomic level neighborhood (Table 1$)$.

\section{Characteristics, target areas and quality of parks}

The mean number of people within 500 meters of parks was 7,398 $\pm 1,887$ and the size of parks was $10,306.8 \pm 8,929.2 \mathrm{~m}^{2}$. Nonetheless, the socioeconomic level was not associated with these variables $(\mathrm{p}=0.103)$ (table 2).

A total of 139 target areas were mapped and observed with a mean size of $2,757.2 \pm 1,317.6 \mathrm{~m}^{2}$. The parks with high socioeconomic level show more areas (84 versus 55). The socioeconomic level was not associated with the mean size of areas $(\mathrm{p} \geq 0.421)$ (table 2). Sports courts (41.4\%) and walking paths (4.5\%) were, respectively, the most and least observed areas (table 2).

Most target areas were accessible (99.0\%), usable (97.4\%) and supervised (69.9\%). About $2.3 \%$ of areas were equipped and $0.2 \%$ was dark (table 2 ). In parks with high socioeconomic levels more usable (100\%) and supervised (99.7\%) areas were observed when compared to low socioeconomic level (usable: 94.7\%; supervised: 40.1\%) (table 2). Parks with low socioeconomic level showed high number of areas that was equipped (4.5\%) and dark $(0.4 \%)$ when compared to high socioeconomic level (equipped: $0.1 \%$; dark: $0.0 \%)$. Nevertheless, the conditions of the area for physical activity were not associated to socioeconomic level ( $\mathrm{p} \geq 0.095$ ) (table 2).

The socioeconomic level was positively associated with the presence of walking paths ( 7.5 versus $1.4 \% ; \mathrm{p}=0.056)$, the accessibility score $(2.8 \pm 0.4$ versus $1.2 \pm 0.4 ; \mathrm{p}=0.001)$ and general quality $(30.4 \pm 4.6$ versus $41.6 \pm 9.5$; $\mathrm{p}=0.039$ ) of the parks (table 2 ). The low socioeconomic level was associated to the presence of sports courts $(\mathrm{p}=0.032)$.

\section{DISCUSSION}

This is the first study to evaluate the association between the socioeconomic level of neighborhoods and the characteristics and quality of parks for physical activity in an intermediate city in Latin America. The results showed that the socioeconomic level was not associated with most of the variables analyzed. Parks located in high socioeconomic neighborhoods scored higher in most structured for physical activity, benefits for users, 


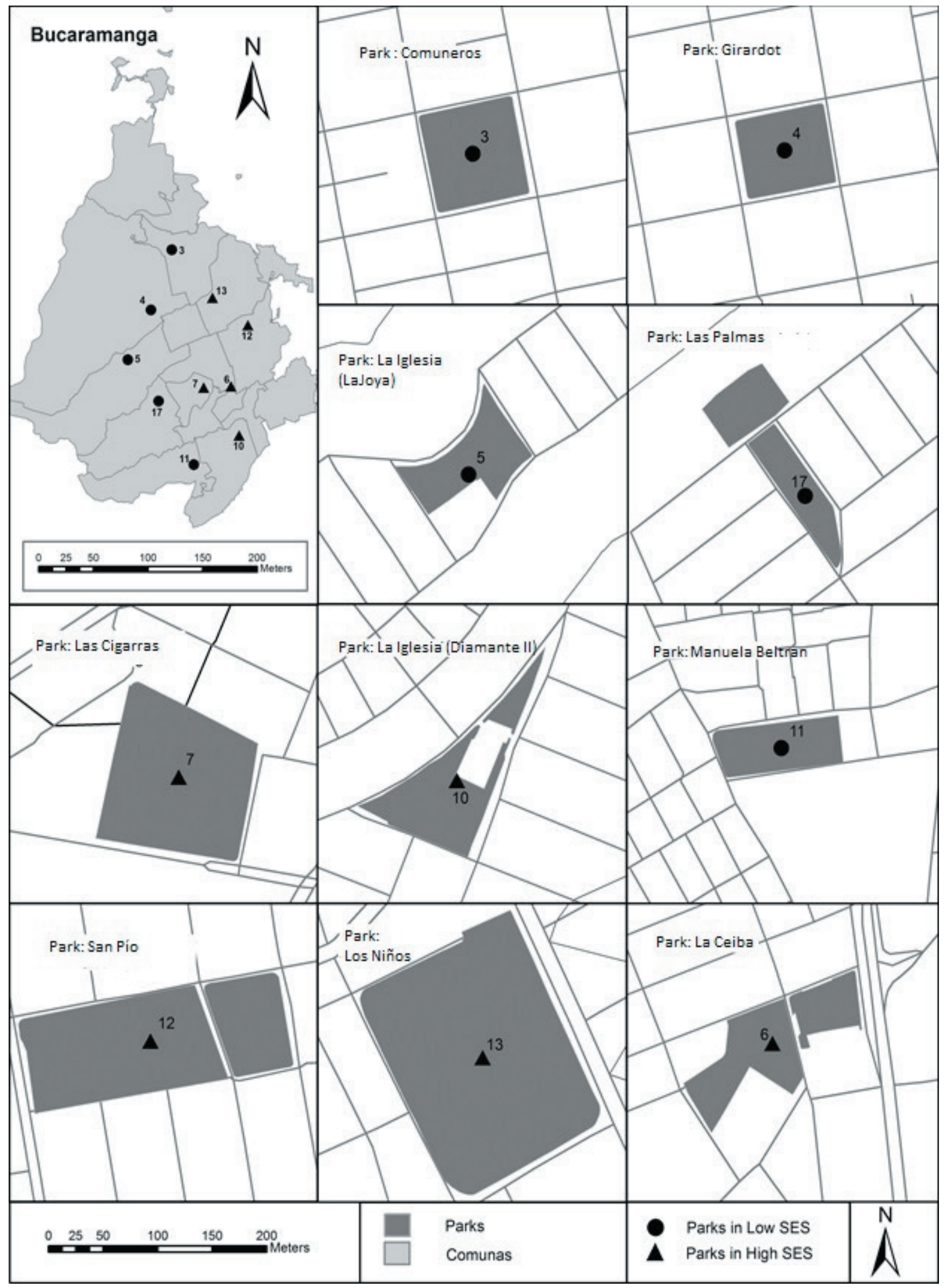

Figure 1: Parks by socioeconomic status. Bucaramanga, Colombia, $2015(n=10)$. 
Table 1: Descriptive characteristics of parks, by socioeconomic level. Bucaramanga, Colombia, 2015 ( $n=10)$.

\begin{tabular}{|c|c|c|c|c|c|c|c|}
\hline $\begin{array}{l}\text { Neighborhood } \\
\text { socioeconomic } \\
\text { level }\end{array}$ & $\begin{array}{l}\text { Region so- } \\
\text { cioeconomic } \\
\text { level }\end{array}$ & Park & $\begin{array}{c}\text { Number of } \\
\text { people within } \\
500 \mathrm{~m}\end{array}$ & $\begin{array}{c}\text { Size of park } \\
\left(\mathrm{m}^{2}\right)\end{array}$ & $\begin{array}{l}\text { Number of ar- } \\
\text { eas for physi- } \\
\text { cal activity }\end{array}$ & $\begin{array}{l}\text { Total area size } \\
\text { for physical } \\
\text { activity }\left(\mathrm{m}^{2}\right)\end{array}$ & $\begin{array}{l}\text { Mean target ar- } \\
\text { eas for physical } \\
\text { activity }\left(\mathrm{m}^{2}\right)\end{array}$ \\
\hline \multirow[t]{7}{*}{ Low } & 1 & Manuela Beltrán & 10,821 & $4,553.4$ & 11 & $2,025.8$ & 184.2 \\
\hline & 2 & Girardot & 9,448 & $5,645.8$ & 14 & $3,185.0$ & 227.5 \\
\hline & 3 & Comuneros & 9,176 & $7,161.8$ & 11 & $3,588.9$ & 326.3 \\
\hline & 3 & $\begin{array}{l}\text { La Iglesia } \\
\text { (La Joya) }\end{array}$ & 4,679 & $4,183.6$ & 10 & $1,050.0$ & 105.0 \\
\hline & 3 & Las Palmas & 6,931 & $6,480.9$ & 9 & $3,199.8$ & 355.5 \\
\hline & 4 & La Ceiba & 6,281 & $5,553.2$ & 14 & $1,692.0$ & 120.9 \\
\hline & 4 & Las Cigarras & 6,840 & $15,034.3$ & 14 & $2,926.4$ & 209.0 \\
\hline \multirow[t]{3}{*}{ High } & 4 & $\begin{array}{l}\text { La Iglesia } \\
\text { (Diamante II) }\end{array}$ & 5,811 & $4,671.4$ & 17 & $2,076.0$ & 122.1 \\
\hline & 4 & De Los Niños & 6,317 & $31,912.5$ & 24 & $5,758.2$ & 239.9 \\
\hline & 6 & San Pio & 7,677 & $17,870.8$ & 15 & $2,070.2$ & 138.0 \\
\hline
\end{tabular}

Table 2: Association between socioeconomic level, characteristics and quality of public urban parks for physical activity. Bucaramanga, Colombia, $2015(n=10)$.

\begin{tabular}{|c|c|c|c|c|c|c|}
\hline & $\begin{array}{c}\text { Low } \\
(n=5)\end{array}$ & $\begin{array}{l}\text { High } \\
(n=5)\end{array}$ & sig. ${ }^{a}$ & $\begin{array}{c}\text { All } \\
(n=10)\end{array}$ & Rho & sig. \\
\hline \multicolumn{7}{|c|}{ Number of people within $500 \mathrm{~m}$} \\
\hline Average \pm SD & $8,211 \pm 2418$ & $6,585 \pm 711$ & 0.222 & $7,398 \pm 1,887$ & -0.500 & 0.141 \\
\hline $\min .-\max$ & $4,679-10,821$ & $5,811-7,677$ & & $4,679-10,821$ & & \\
\hline \multicolumn{7}{|l|}{ Size of park $\left(m^{2}\right)$} \\
\hline Average \pm SD & $5,605.1 \pm 1256.9$ & $15,008.4 \pm 11,070.2$ & 0.174 & $10,306.8 \pm 8,929.2$ & 0.545 & 0.103 \\
\hline min. - max. & $4,183.6-6,480.9$ & $4,671.4-31912.5$ & & $4,183.6-3,1912.5$ & & \\
\hline \multicolumn{7}{|c|}{ Target areas for physical activity } \\
\hline Number & 55 & 84 & - & 139 & & \\
\hline Percentage & 39.6 & 60.4 & - & 100.0 & & \\
\hline Total size $\left(m^{2}\right)$ & $1,3049.5$ & $1,4522.8$ & - & $27,572.3$ & - & \\
\hline Average \pm SD & $2,609.9 \pm 1,050.2$ & $2,904.6 \pm 1658.1$ & 0.943 & $2,757.2 \pm 1,317.6$ & 0.013 & 0.972 \\
\hline $\min .-\max$ & $1,050.0-3,588.9$ & $1,692.0-5,758.2$ & & $1,050.0-5,758.2$ & & \\
\hline \multicolumn{7}{|l|}{ Size by area $\left(m^{2}\right)$} \\
\hline Average \pm SD & $239.7 \pm 102.8$ & $165.9 \pm 54.9$ & 0.421 & $202.8 \pm 86.9$ & -0.266 & 0.457 \\
\hline min. - max. & $105.0-355.5$ & $120.9-239.9$ & & $105.0-355.5$ & & \\
\hline \multicolumn{7}{|c|}{ Type of target area for physical activity (\%) } \\
\hline Sports courts & 54.5 & 28.3 & 0.032 & 41.4 & - & - \\
\hline Child play & 23.7 & 23.0 & 1.000 & 23.3 & - & - \\
\hline Fitness Zones & 13.5 & 18.6 & 0.690 & 16.1 & - & - \\
\hline Strength training & 6.9 & 10.5 & 0.841 & 8.6 & - & - \\
\hline Green areas* & 0.0 & 12.1 & 0.310 & 6.1 & - & - \\
\hline Walking paths & 1.4 & 7.5 & 0.056 & 4.5 & - & - \\
\hline \multicolumn{7}{|c|}{ Conditions of target areas for physical activity (\%) } \\
\hline Accessible & 98.0 & 99.8 & 0.690 & 99.0 & - & - \\
\hline Usable & 94.7 & 100.0 & 0.548 & 97.4 & - & - \\
\hline Supervised & 40.1 & 99.7 & 0.095 & 69.9 & - & - \\
\hline Empty & 54.3 & 45.2 & 0.421 & 49.8 & - & - \\
\hline Organized & 3.8 & 2.5 & 0.690 & 3.1 & - & - \\
\hline Equipped & 4.5 & 0.1 & 0.841 & 2.3 & - & - \\
\hline Dark & 0.4 & 0.0 & 0.690 & 0.2 & - & - \\
\hline
\end{tabular}

Continue.. 
.. continue

\begin{tabular}{|c|c|c|c|c|c|c|}
\hline & $\begin{array}{l}\text { Low } \\
(n=5)\end{array}$ & $\begin{array}{l}\text { High } \\
(n=5)\end{array}$ & sig. ${ }^{a}$ & $\begin{array}{c}\text { All } \\
(n=10)\end{array}$ & Rho & sig. \\
\hline \multicolumn{7}{|l|}{ Park quality (score) } \\
\hline \multicolumn{7}{|c|}{ Structure for physical activity } \\
\hline Average \pm SD & $10.2 \pm 1.9$ & $16.6 \pm 6.4$ & \multirow[t]{2}{*}{0.095} & $13.4 \pm 5.6$ & 0.504 & 0.138 \\
\hline $\min .-\max$ & $8.0-13.0$ & $8.0-25.0$ & & $8.0-25.0$ & & \\
\hline \multicolumn{7}{|c|}{ Structure for user benefit } \\
\hline Average $\pm S D$ & $7.2 \pm 1.9$ & $8.4 \pm 1.5$ & \multirow[t]{2}{*}{0.310} & $7.8 \pm 1.8$ & 0.244 & 0.497 \\
\hline $\min .-\max$ & $5.0-10.0$ & $6.0-10.0$ & & $5.0-10.0$ & & \\
\hline \multicolumn{7}{|c|}{ Cleanliness. aesthetics and safety } \\
\hline Average \pm SD & $10.2 \pm 1.6$ & $10.0 \pm 2.4$ & \multirow[t]{2}{*}{0.548} & $10.1 \pm 1.9$ & 0.091 & 0.803 \\
\hline min. - max. & $9.0-13.0$ & $8.0-13.0$ & & $8.0-13.0$ & & \\
\hline \multicolumn{7}{|l|}{ Services } \\
\hline Average \pm SD & $0.8 \pm 1.1$ & $2.0 \pm 0.7$ & \multirow[t]{2}{*}{0.151} & $1.4 \pm 1.1$ & 0.514 & 0.129 \\
\hline $\min .-\max$ & $0.0-2.0$ & $1.0-3.0$ & & $0.0-3.0$ & & \\
\hline \multicolumn{7}{|l|}{ Accessibility } \\
\hline Average \pm SD & $1.2 \pm 0.5$ & $2.8 \pm 0.5$ & \multirow[t]{2}{*}{0.008} & $2.0 \pm 0.9$ & 0.875 & 0.001 \\
\hline $\min .-\max$ & $1.0-2.0$ & $2.0-3.0$ & & $1.0-3.0$ & & \\
\hline \multicolumn{7}{|l|}{ Safety against crime } \\
\hline Average \pm SD & $0.8 \pm 1.1$ & $1.6 \pm 1.3$ & 0.310 & $1.2 \pm 1.2$ & 0.429 & 0.216 \\
\hline $\min .-\max$ & $0.0-3.0$ & $0.0-3.0$ & & $0.0-3.0$ & & \\
\hline General quality** & $30.4 \pm 4.6$ & $41.6 \pm 9.5$ & 0.056 & $35.9 \pm 9.1$ & 0.657 & 0.039 \\
\hline $\min .-\max$ & $26.0-37.0$ & $27.0-52.0$ & & $26.0-52.0$ & & \\
\hline
\end{tabular}

SD: standard deviation; min.: minimum; max.: maximum; rho: Spearman correlation coefficient for association with region socioeconomic level; a: U Mann Whitney test; * Green areas, plazas, roundabouts; ${ }^{*}$ General quality = score for structures for physical activity + structures' for user benefit + cleanliness, aesthetics and safety + services + accessibility + safety against crime.

services and safety against crime. The methods used allowed to represent the parks according to socioeconomic level of the neighborhoods, describe and compare its structures for physical activity, which is one of the strong of this study. Previous studies conducted in Latin America have only described the conditions of parks, but not relate it to neighborhood socioeconomic leve ${ }^{19,20}$. This information should be used for better decision-making in public investment for the promotion of physical activity in the population of Bucaramanga.

The socioeconomic level was not associated to the mean number of people living within 500 meters from parks ( $\mathrm{p}=0.141)$. In Pelotas, Brazil, Silva et. al. ${ }^{20}$ verified inverse relationship between population density and number of available spaces for physical activity. The population density around the parks may represent potential users, so it is necessary to generate public policy to improve the quality conditions of parks and establish strategies to motive the active use of those parks ${ }^{30}$.

In the present study, there was no significant association between the socioeconomic level and the size of parks $(\mathrm{p}=0.103)$. However, parks in high socioeconomic level neighborhoods area almost three times larger $\left(15,008.4\right.$ versus $\left.5,468.9 \mathrm{~m}^{2}\right)$. Cohen et. al. ${ }^{30}$ conducted a study in 174 parks of 25 cities in the United States and verified the positive association between socioeconomic level and size of parks (10.0 versus 7.8 acres, 
$p=0.003)$. The lack of association in this study can be explained by the small number of parks in the sample and their great variability in size. In fact, the assessed parks in high socioeconomic level neighborhoods are larger in total area, but average size of physical activity areas is similar to those parks assessed in low socioeconomic level neighborhoods $(2,904.6$ versus 2,609.9 $\mathrm{m}^{2}, \mathrm{p}=0.943$ ).

Low socioeconomic level parks presented a higher proportion of sports courts (54.4\% versus $28.3 \%$, $\mathrm{p}=0.032$ ); meanwhile, the parks in high socioeconomic level have a higher proportion of walking paths (7.5 versus $1.4 \%$, $\mathrm{p}=0.056)$ and green areas (12.1 versus $0.0 \%)$. The general proportion of sports areas, such as courts (41.4\%), child play (23.3\%), areas for strength training (8.6\%) and green areas (6.1\%) found in this study were similar to those in parks and plazas in Curitiba, Brazil (sports areas: $\approx 54 \%$; child play: $\approx 20.6 \%$; strength training: $\approx 7.4 \%$; green areas: $\approx 4 \%)^{8}$. The higher proportion of green areas in parks of high socioeconomic level could represent a higher benefit to the users, once the trees and green areas reduce pollution, moderate the temperature allowing shade and cooling of the areas where they are located ${ }^{2}$. Moreover, the perceived attractiveness of the park and its elements, such as characteristics of design, the landscape, balance between sun and shade and the visual attractiveness could represent a determinant factor in making the decision to use parks ${ }^{9,19,20}$. This is especially important in Bucaramanga where temperatures through the year are a mean of $23^{\circ} \mathrm{C}$.

In the present study, $99.0 \%$ of the target areas were accessible and $97.4 \%$, usable. These are similar to the studies found in a systematic review describing the accessibility between $82-100 \%$ and usability between 85 $100 \%{ }^{16}$. However, parks in low socioeconomic level neighborhoods had supervision in $40.1 \%$ of the time; in contrast with $99.7 \%$ of parks in high socioeconomic levels areas ${ }^{30}$. Cohen et. al. ${ }^{30}$ highlighted that parks with higher poverty had less supervised areas when compared to those of lower level of poverty ( 2.1 versus $4.5 ; \mathrm{p}=0.012$ ). Furthermore, for every additional area with supervised activities, the mean use of park increased in $48 \%$ and the mean time in moderate to vigorous physical activity in $37 \%{ }^{16}$. This is the essence to increase the levels of physical activity in the community ${ }^{8}$. Evenson et. al. ${ }^{16}$ point that the aspects least found in parks were organized (range 0-31\%), equipped (range 0-15\%) and supervised (0-31\%) areas.

A positive and significant association was found between socioeconomic level and accessibility and general quality of parks. The accessibility is important once it evaluates the capacity of parks to allow people to get to them from different means such as bus, car, motorcycle or bicycle, for physical activity ${ }^{2}$. On the contrary, Cohen et. al. ${ }^{30}$, did not find differences between socioeconomic level and accessibility. However, Vieira et al. ${ }^{12}$ found significant positive association between the level of social development of a neighborhood and quality of parks for physical activity in Rio de Janeiro, Brazil. This can partially explain the association found between living in low income areas and level of social development, with lower levels of physical activity ${ }^{13-15}$. 
A few limitations need to be considered for the adequate interpretation and extrapolation of the results of this study. The parks were selected by convenience and their potential for physical activity in the community. Therefore, there is no total representation of the regions. The sample did not include five regions from the 17 total, due to the fact that there were no parks fitting the inclusion criteria; additionally, 2/17 parks could not be evaluated due to lack of safety.

\section{CONCLUSION}

A positive association was found between the socioeconomic level and the presence of walking paths, accessibility and general quality of parks. The low socioeconomic level was associated to the presence of sports courts.

These results can be a tool to support manager to fundament their actions based in the modification of the community environment for promotion of physical activity. It is necessary to improve the quality of parks in low income neighborhoods to attract the population to those places. The improvement in the quality of parks is a promising initiative to increase weekly frequency of use of parks for physical activity in costless and accessible locations for the entire community. Other studies could evaluate the perception of the people concerning the parks and the factors related to use for physical activity. This is important to know how sociodemographic and cultural characteristics and the perception of parks can be associated to their use. Also, future studies in Latin America should assess the effect of implementation and/or improvement in quality of parks and levels of physical activity in the community.

\section{Funding}

This study was funded by COLCIENCIAS, \#686-2014 (project 110265740960).

\section{REFERENCES}

1. Sallis JF, Bull F, Guthold R, Heath GW, Inoue S, Kelly P, et al. Progress in physical activity over the Olympic Quadrennium. Lancet 2016; 388(10051):1325-36.

2. Bedimo-Rung AL, Mowen AJ, Cohen DA. The significance of parks to physical activity and public health: a conceptual model. Am J Prev Med 2005; 28(2 Suppl 2):159-68

3. Cohen DA, McKenzie TL, Sehgal A, Williamson S, Golinelli D, Lurie N. Contribution of public parks to physical activity. Am J Public Health 2007;97(3):509-14.

4. Fermino RC, Reis RS. Individual, environmental and social variables associated with the use of public open spaces for physical activity practices: a systematic review. Rev Bras Ativ Fis Saúde 2013;18(5):523-35.

5. Salvo D, Sarmiento OL, Reis RS, Hino AA, Bolivar MA, Lemoine PD, et al. Where latin americans are physically active, and why does it matter? findings from the IPEN-adult study in Bogota, Colombia; Cuernavaca, Mexico; and Curitiba, Brazil. Prev Med 2016; S0091-7435(16)30264-X.

6. McCormack GR, Rock M, Toohey AM, Hignell D. Characteristics of urban parks associated with park use and physical activity: a review of qualitative research. Health Place 2010;16(4):712-26. 
7. Cohen DA, Marsh T, Williamson S, Derose KP, Martinez H, Setodji C, et al. Parks and physical activity: why are some parks used more than others? Prev Med 2010;50 (Suppl 1):S9-12.

8. Hino AAF, Reis RS, Ribeiro IC, Parra DC, Brownson RC, Fermino RC. Using observational methods to evaluate public open spaces and physical activity in Brazil. J Phys Act Health 2010;7:(Suppl 2):S146-54.

9. Fermino RC, Reis RS, Hallal PC, Kaczynski AT. Who are the users of urban parks? a study with adults from Curitiba, Brazil. J Phys Act Health 2015;12(1):58-67.

10. Fermino RC, Reis RS, Hallal PC, de Farias Junior JC. Perceived environment and public open space use: a study with adults from Curitiba, Brazil. Int J Behav Nutr Phys Act 2013;10(35):1-10.

11. Lima AV, Fermino RC, Oliveira MP, Rodriguez Anez CR, Reis RS. Perceived distance to recreational facilities and the association with physical activity and exercise among adolescents in Curitiba, Parana State, Brazil. Cad Saude Publica 2013;29(8):1507-21.

12. Vieira MC, Sperandei S, Reis A, da Silva CG. An analysis of the suitability of public spaces to physical activity practice in Rio De Janeiro, Brazil. Prev Med 2013;57(3):198-200.

13. Lee RE, Mama SK, McAlexander KP, Adamus H, Medina AV. Neighborhood and PA: neighborhood factors and physical activity in African American public housing residents. J Phys Act Health 2011;8(Suppl 1):S83-90.

14. Lee RE, Mama SK, Adamus-Leach HJ, Soltero EG. Contribution of neighborhood income and access to quality physical activity resources to physical activity in ethnic minority women over time. Am J Health Promot 2015;29(4):210-6.

15. Hino AA, Reis RS, Sarmiento OL, Parra DC, Brownson RC. The built environment and recreational physical activity among adults in Curitiba, Brazil. Prev Med 2011;52(6):419-22.

16. Evenson KR, Jones SA, Holliday KM, Cohen DA, McKenzie TL. Park characteristics, use, and physical activity: a review of studies using SOPARC (System for Observing Play and Recreation in Communities). Prev Med 2016;86:153-66.

17. Bancroft C, Joshi S, Rundle A, Hutson M, Chong C, Weiss CC, et al. Association of proximity and density of parks and objectively measured physical activity in the United States: a systematic review. Soc Sci Med 2015;138:22-30.

18. Joseph RP, Maddock JE. Observational park-based physical activity studies: a systematic review of the literature. Prev Med 2016;89:257-77.

19. Silva MC, Silva BA, Costa ATE. Public area conditions and physical activity practice in the city of Pelotas-RS, Brazil. Rev Bras Ativ Fis Saúde 2012;17(1):28-32.

20. Silva I, Mielke G, Nunes B, Böhm A, Cruz M, Blanke A, et al. Public open spaces in Pelotas (Brazil): distribution, quality and suitability for physical activity practice. Rev Bras Ativ Fis Saúde 2015;20(1):82-92.

21. Alcaldia de Bucaramanga, Secretaria de Planeación. Documento técnico de soporte de la revisión del plan de ordenamiento territorial del municipio de Bucaramanga 2013-2017. [cited 2016 Aug 16]. Available from: http://www.concejodebucaramanga.gov.co/planordenamientoterritorial/tomo1.pdf.

22. McKenzie TL, Cohen DA. Tools and measures SOPARC: System for Observing Play and Recreation in Communities. 2006. [cited 2016 Dec 15]. Available from: http://activelivingresearch.org/soparc-system-observing-play-and-recreationcommunities.

23. Departamento Nacional de Estadística. Estratificación socioeconómica: 2015; [cited 2016 Jan 24]. Available from: http://www.dane.gov.co/index.php/estratificacion-socioeconomica/generalidades.

24. Departamento Nacional de Estadística. Censo General: 2005. [cited 2016 Jan 24] [Available from: https://www.dane.gov.co/files/censos/libroCenso2005nacional.pdf.

25. McKenzie TL, Cohen DA, Sehgal A, Williamson S, Golinelli D. System for Observing Play and Recreation in Communities (SOPARC): reliability and feasibility measures. J Phys Act Health 2006;3(Suppl 1):S208-s22. 
26. Parra DC, McKenzie TL, Ribeiro IC, Ferreira Hino AA, Dreisinger M, Coniglio $\mathrm{K}$, et al. Assessing physical activity in public parks in Brazil using systematic observation. Am J Public Health 2010;100(8):1420-6.

27. Santos MPM, Rech CR, Alberico CO, Fermino RC, Rios AP, David J, et al. Utility and reliability of an app for the System for Observing Play and Recreation in Communities (ISOPARC ${ }^{\circledR}$ ). Meas Phys Educ Exerc Scie 2016;20(2):93-8.

28. Lee RE, Booth KM, Reese-Smith JY, Regan G, Howard HH. The Physical Activity Resource Assessment (PARA) Instrument: evaluating features, amenities and incivilities of physical activity resources in urban neighborhoods. Int J Behav Nutr Phys Act 2005;2:13.

29. Hino AA. Medidas objetivas e percebidas do ambiente do bairro e sua associação com a atividade física de lazer em adultos de Curitiba [Dissertation]. Curitiba, Brazil: Universidade Federal do Paraná; 2014.

30. Cohen DA, Han B, Nagel CJ, Harnik P, McKenzie TL, Evenson KR, et al. The first national study of neighborhood parks: implications for physical activity. Am J Prev Med 2016;51(4):419-26.

\section{CORRESPONDING AUTHOR}

Paula C. Ramírez Industrial University of Santander. School of Physical Therapy. Research Group in Movement, Harmony and Life (MAV). Bucaramanga, Colombia Carrera 32, no 29-31, Bucaramanga E-mail:pcramire@uis.edu.co 